\title{
Design, Implementation and Perceptions of Safety Culture Prerequisites
}

\author{
Nektarios Karanikas ${ }^{1,}{ }^{*}$, Alfred Roelen ${ }^{2}$ and Alistair Vardy ${ }^{1}$ \\ ${ }^{1}$ Amsterdam University of Applied Sciences, The Netherlands \\ ${ }^{2}$ Netherlands Aerospace Centre, The Netherlands
}

\begin{abstract}
In the frame of an on-going 4-years research project, the Aviation Academy Safety Culture Prerequisites (AVAC-SCP) metric was developed to assess whether an organisation plans and implements activities that correspond to prerequisites for fostering a positive safety culture. The metric was designed based on an inclusive theoretical framework stemmed from academic and professional literature and in cooperation with knowledge experts and aviation companies. The goal of the AVAC-SCP is to evaluate three aspects, namely (1) the extent to which the prerequisites are designed/documented, (2) the degree of the prerequisites' implementation, and (3) the perceptions of the employees regarding the organizational safety culture as a proxy for the effectiveness of the prerequisites' implementation. The prerequisites have been grouped into six categories (common prerequisites and just, flexible, reporting, information and learning cultures) and the metric concludes with scores per aspect and category. The results from surveys at 16 aviation companies showed that these companies had adequately included most of the Safety Culture Prerequisites (SCP) in their documentation where Just culture plans scored the lowest and Reporting culture plans were found with the highest percentage of planning. The level of SCP implementation was the same high as the organisational plans and quite uniform across the companies and sub-cultures. The perceptions were at the same overall level with implementation, but employees perceived the organisational environment as less fair and more flexible than managers claimed. Although the study described in this report was exploratory and not explanatory, we believe that the results presented in combination with the ones communicated to the participating companies can trigger the latter to investigate further their weaker areas and foster their activities related to Safety Culture Prerequisites. Also, the AVAC-SCP metric is deemed useful to organisations that want to self-assess their SCP levels and proceed to comparisons amongst various functions and levels and/or over time.
\end{abstract}

Keywords: Safety Culture; Safety Culture Prerequisites; Safety Culture Planning; Safety Culture Implementation.

\section{INTRODUCTION}

In September 2015, the Aviation Academy of the Amsterdam University of Applied Sciences initiated the research project entitled "Measuring Safety in Aviation - Developing Metrics for Safety Management Systems" which is co-funded by the Regieorgaan Praktijkgericht Onderzoek SIA ${ }^{\dagger}$. The project responds to three specific needs of the aviation industry as these were expressed during a roundtable in September 2014 (Aviation Academy, 2014) and confirmed during the first phase of the research (Karanikas, Kaspers, Roelen, Piric, \& de Boer, 2016b; Kaspers, Karanikas, Roelen, Piric, \& de Boer, in press): (1) Small and Medium Enterprises (SME) lack large amounts of safety-related data to measure and demonstrate their safety performance proactively, (2) large companies might

\footnotetext{
* Corresponding author: +31(0)621156287, n.karanikas@hva.nl, nektkar@gmail.com

$\dagger$ http://www.regieorgaan-sia.nl/
} 
obtain abundant data, but they need safety metrics which are more leading than the current ones and of better quality and (3) the transition from compliance-based to performance-based evaluations of safety is not yet backed with specific tools and techniques. Therefore, the research aimed to identify ways to measure safety proactively in scientifically rigorous, meaningful and practical ways without the benefit of large amounts of data and with an emphasis on performance rather than mere compliance (Aviation Academy, 2014). Following the mapping of the current situation through literature review (Karanikas, Kaspers, Roelen, Piric, \& de Boer, 2016b; Kaspers, Karanikas, Roelen, Piric, \& de Boer, in press), a survey regarding the currently used metrics (Karanikas, Kaspers, Roelen, Piric, van Aalst \& de Boer, 2016a; Kaspers, Karanikas, Roelen, Piric, van Aalst \& de Boer, 2016; Kaspers, et al., 2017) and the design of new safety metrics (Karanikas et al., 2017), the safety current paper focuses on the metric designed for the self-assessment of Safety Culture Prerequisites (SCP) (Piric, et al., 2018).

The Aviation Academy Safety Culture Prerequisites tool (named as AVAC-SCP) was based on a previously published framework (Karanikas et al., 2016c) and combined 37 prerequisites to foster a positive safety culture. The prerequisites are clustered in six categories following Reason's (1998) typology of safety culture (i.e. just, flexible, reporting, informative and learning sub-cultures) and one additional category named general organisational prerequisites. The original objective of the tool was to gain insights into what prerequisites an organisation has included in their safety plans and to what degree the organisation safety culture plans are operationalised. Each of the prerequisites was transformed into questions to be answered by (1) safety managers who must check the organisational documentation to detect whether each prerequisite is present, and (2) safety and line managers regarding the implementation of the corresponding prerequisite.

However, the added value of the perception of safety culture aspects by the workforce could not be neglected; regardless of the efforts of a company to foster a positive safety culture, the perception of the workforce might differ from the intended outcomes of implemented plans. Therefore, in its final version (Figure 1), the AVAC-SCP was complemented with ten questions used to capture the perception of the employees and based on a condensed version of an existing safety culture assessment tool (NLR, 2016). The selection of only ten perception questions followed the advice given during the peer-review of the specific metric to decrease the number of questions addressed to frontline staff as a means to minimise the time needed to fill in the questionnaire and avoid boredom, tiredness or socially desirable answers when responding. Each assessment area results to an overall score which is used to evaluate the gaps between planning, implementation and perception, which, in turn, reflect the gaps between Work-as-Done (WaD) and Work-as-Imagined (Wal) at two different levels (i.e. safety department - managers, and managers-employees).

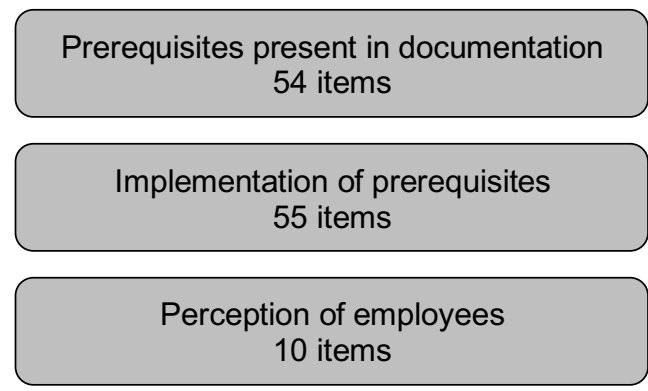

Figure 1: The structure of the AVAC-SCP tool

\section{METHODOLOGY}

Three questionnaires targeted to the following aspects of safety culture development: (a) Organizational plans: whether the company has designed/documented each of the prerequisites. (b) Implementation: the extent to which the prerequisites are realised by the managers/supervisors across various organisational levels and (c) Perception: the degree to which frontline employees perceive the effects of managers' actions related to safety culture. 
The 16 companies which participated in the study were asked to fill out the questionnaires on a self-assessment basis and they were instructed to assess all three aspects; the estimated time investment was 4 hours for the Organizational plans (Safety Department), 0.3 hours for the Implementation (Managers) and 0.17 hours for the Perception questionnaires (Frontline Employees). The companies were prompted to consider the time investment to engage as many managers and employees as possible; the possibly different overall scores between management and frontline staff would indicate a respective vertical gap between what managers do to foster a positive safety culture and how workers perceive aspects of the latter. Table 1 shows the participation per company and questionnaire (denoted by " $X$ ") and reports in brackets the data points per case.

The Organisational plans excluded (i.e. the specific questionnaires were targeted only to the safety department, and a single data point was the minimum required), the participation of employees in the rest of the SCP areas was not representative of the population of most of the companies. Therefore, the results for the whole sample could be only indicative.

Table 1 Participation in the three SCP questionnaires; numbers of employees per company

\begin{tabular}{|c|c|c|c|}
\hline $\begin{array}{l}\text { Company } \\
\text { code }\end{array}$ & $\begin{array}{c}\text { Organisational plans } \\
\text { (sample size in } \\
\text { brackets) }\end{array}$ & $\begin{array}{c}\text { Implementation } \\
\text { (sample size in brackets) }\end{array}$ & $\begin{array}{c}\text { Perception } \\
\text { (sample size in brackets) }\end{array}$ \\
\hline 10629 & $\mathrm{X}(2)$ & $X(5)$ & $\mathrm{X}(11)$ \\
\hline 10862 & $X(1)$ & $X(8)$ & $\mathrm{X}(3)$ \\
\hline 12179 & $X(4)$ & $X(1)$ & $X(9)$ \\
\hline 12821 & $X(3)$ & $X(5)$ & $\mathrm{X}(6)$ \\
\hline 12903 & $X(2)$ & $X(16)$ & $X(39)$ \\
\hline 15108 & $X(5)$ & $\mathrm{X}(18)$ & $\mathrm{X}(49)$ \\
\hline 15521 & $X(1)$ & $\mathrm{X}(2)$ & $X(1)$ \\
\hline 15634 & $X(3)$ & $X(50)$ & $X(196)$ \\
\hline 16539 & $X(1)$ & $X(1)$ & $X(1)$ \\
\hline 16652 & $X(1)$ & & \\
\hline 17029 & $X(2)$ & $X(2)$ & \\
\hline 17387 & $X(1)$ & $X(1)$ & $X(5)$ \\
\hline 20132 & & $X(1)$ & \\
\hline 24113 & $X(1)$ & $\mathrm{X}(4)$ & $\mathrm{X}(10)$ \\
\hline 24144 & $X(1)$ & & $X(10)$ \\
\hline 25226 & $X(2)$ & $\mathrm{X}(81)$ & \\
\hline
\end{tabular}

The possible responses for the Organizational plans' questionnaire were Yes/Partially/No. The questions for the Implementation and Perception questionnaires were on a 5-point Likert scale. Two variants were possible depending on the question; these variants were coded to allow calculations (Table 2). Responses coded with "0" were treated as missing values. The responses were coded identically so the two scales could be combined. Since companies were invited to ask multiple employees to participate in the same questionnaire, a single score for each question was obtained by taking the median response over employees.

Table 2 Likert scales for the Implementation and Perception questionnaires

\begin{tabular}{|c|c|c|c|c|c|c|}
\hline $\begin{array}{c}\text { Variant } \\
1\end{array}$ & $\begin{array}{l}\text { Strongly } \\
\text { agree }\end{array}$ & Agree & Undecided & Disagree & $\begin{array}{l}\text { Strongly } \\
\text { disagree }\end{array}$ & \\
\hline $\begin{array}{c}\text { Variant } \\
2 \\
\end{array}$ & Always & $\begin{array}{l}\text { Almost } \\
\text { always }\end{array}$ & Sometimes & $\begin{array}{c}\text { Almost } \\
\text { never }\end{array}$ & Never & $\begin{array}{c}\text { Not } \\
\text { applicable }\end{array}$ \\
\hline Code & 5 & 4 & 3 & 2 & 1 & 0 \\
\hline
\end{tabular}


The questions of the three questionnaires were grouped into so-called Sub-cultures (see section 1 above). Table 3 illustrates the number of questions per different subculture and questionnaire.

Table 3 Number of questions per sub-culture for the three AVAC-SCP questionnaires

\begin{tabular}{|l|c|c|c|}
\hline Sub-culture & $\begin{array}{c}\text { Organizational plans } \\
\text { (54 questions) }\end{array}$ & $\begin{array}{c}\text { Implementation } \\
\text { (55 questions) }\end{array}$ & $\begin{array}{c}\text { Perception } \\
\text { (10 questions) }\end{array}$ \\
\hline General prerequisites & 18 & 19 & 4 \\
\hline Just culture & 6 & 6 & 2 \\
\hline Flexible culture & 5 & 5 & 1 \\
\hline Reporting culture & 9 & 9 & 2 \\
\hline Informative culture & 9 & 9 & 1 \\
\hline Learning culture & 7 & 7 & 2 \\
\hline
\end{tabular}

The overall results were grouped by subculture and calculated as the medians of all responses to the respective questions per element. Associations between the Implementation and Perception scores as well amongst the sub-cultures per assessment aspect were assessed by using the Spearman's correlation coefficient; the statistical significance level was set to 0.05 . As the two questionnaires do not have the same number of items, only the overall scores were correlated. These scores were determined by taking the median of the responses of all questions of the corresponding questionnaire.

\section{RESULTS}

The overall scores per company and assessment area are presented in Table 4, and the results per area and question are reported in Appendix A, where the top $25 \%$ fully or partially documented Organizational plans are coloured in green, and the lowest $25 \%$ in yellow (Table A.1); a similar colour coding is used for the scores of Implementation (Table A.2) and Perception (Table A.3) higher or lower than the median 4. It is noticed that the scores of negatively formulated questions have been inverted. The detailed findings per sub-culture and area assessed per company were communicated to the companies through individual reports.

Table 4 SCP median scores per company and questionnaire

\begin{tabular}{|c|c|c|c|c|}
\hline \multirow{2}{*}{$\begin{array}{l}\text { Company } \\
\text { Code }\end{array}$} & \multicolumn{2}{|c|}{ Organizational plans (\%) } & \multirow{2}{*}{$\begin{array}{l}\text { Implementation } \\
\text { (median) }\end{array}$} & \multirow{2}{*}{$\begin{array}{l}\text { Perception } \\
\text { (median) }\end{array}$} \\
\hline & Yes & Partial & & \\
\hline 10629 & 87 & 0 & 4 & 4 \\
\hline 10862 & 64 & 0 & 4 & 4 \\
\hline 12179 & 85 & 1 & 4 & 4 \\
\hline 12821 & 91 & 1 & 5 & 4 \\
\hline 12903 & 53 & 5 & 4 & 4 \\
\hline 15108 & 71 & 2 & 4 & 4 \\
\hline 15521 & 68 & 0 & 4 & 4,5 \\
\hline 15634 & 100 & 0 & 4 & 4 \\
\hline 16539 & 88 & 1 & 4 & 4 \\
\hline 16652 & 98 & 0 & & \\
\hline 17029 & 79 & 0 & 4 & \\
\hline 17387 & 96 & 0 & 5 & 4 \\
\hline 20132 & & & 4 & \\
\hline 24113 & 77 & 3 & 4 & 4 \\
\hline 24144 & 75 & 1 & & 4 \\
\hline 25226 & 93 & 0 & 4 & \\
\hline
\end{tabular}


Figures 2, 3 and 4 show the overall sample's picture regarding Organisational Plans, Implementation and Perception respectively. The results suggest that Organisational Plans were about $83 \%$ fully or partially present $(\mathrm{N}=15, \mathrm{M}=82.6, \mathrm{SD}=12.83)$; the scores ranged from $53 \%$ to $100 \%$. Just Culture prerequisites were the least represented at the level of $67 \%$, and Reporting Culture prerequisites were $94 \%$ fully or partially included in the organisational plans. The rest of the subcultures concerned, organisational plans were fully or partially existent in $85 \%$ for General prerequisites, $80 \%$ for Flexible culture, $86 \%$ for Informative culture and $78 \%$ for Learning culture.

The Implementation yielded a median of 4 out of 5 in overall and across all subcultures. Employees Perceptions were in overall at the median level similar to Implementation, but staff rated Just Culture elements with the lowest score of 3.5 and the Flexible Culture elements with the highest score of 4.5 .

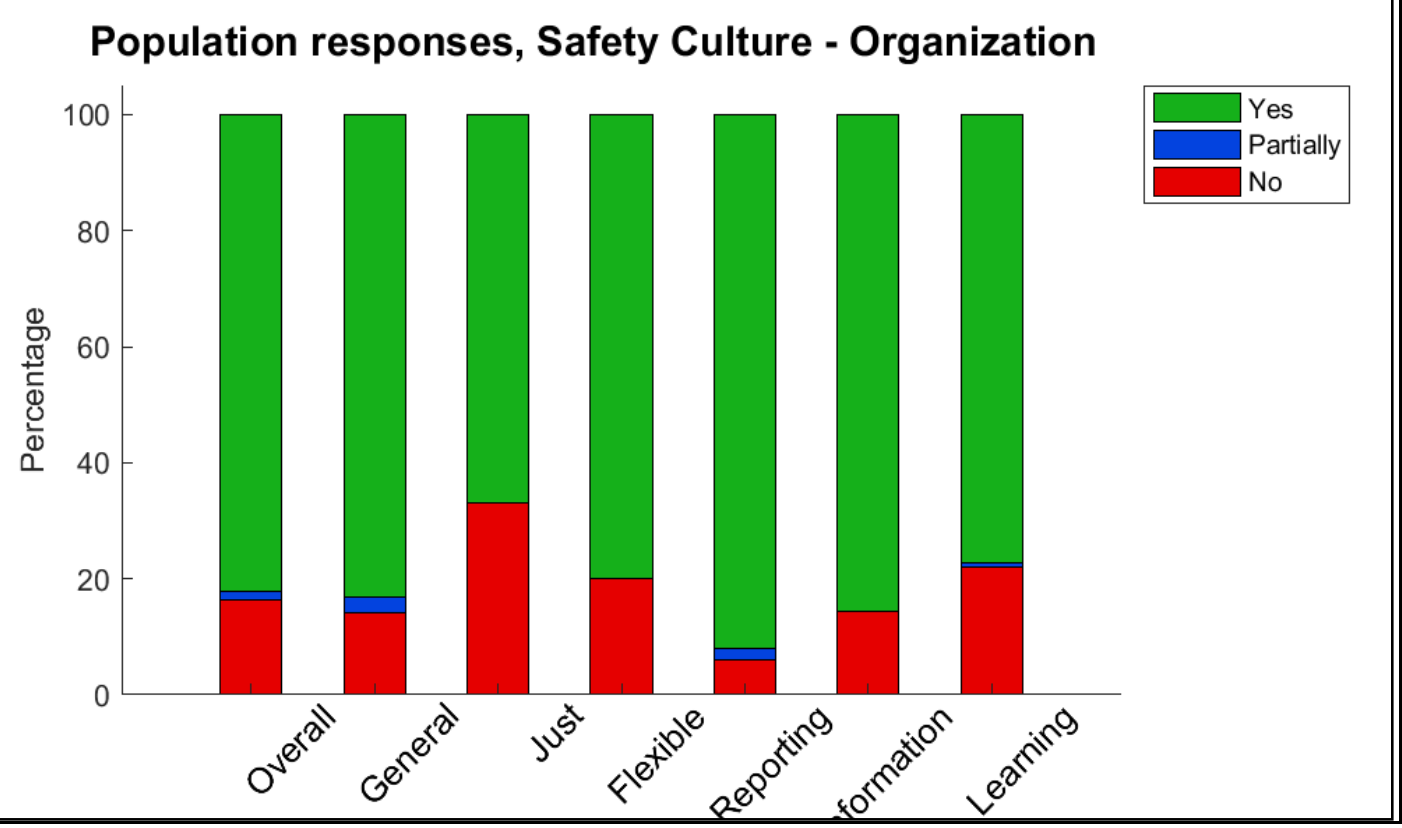

Figure 2: Population scores for the Organizational plans 


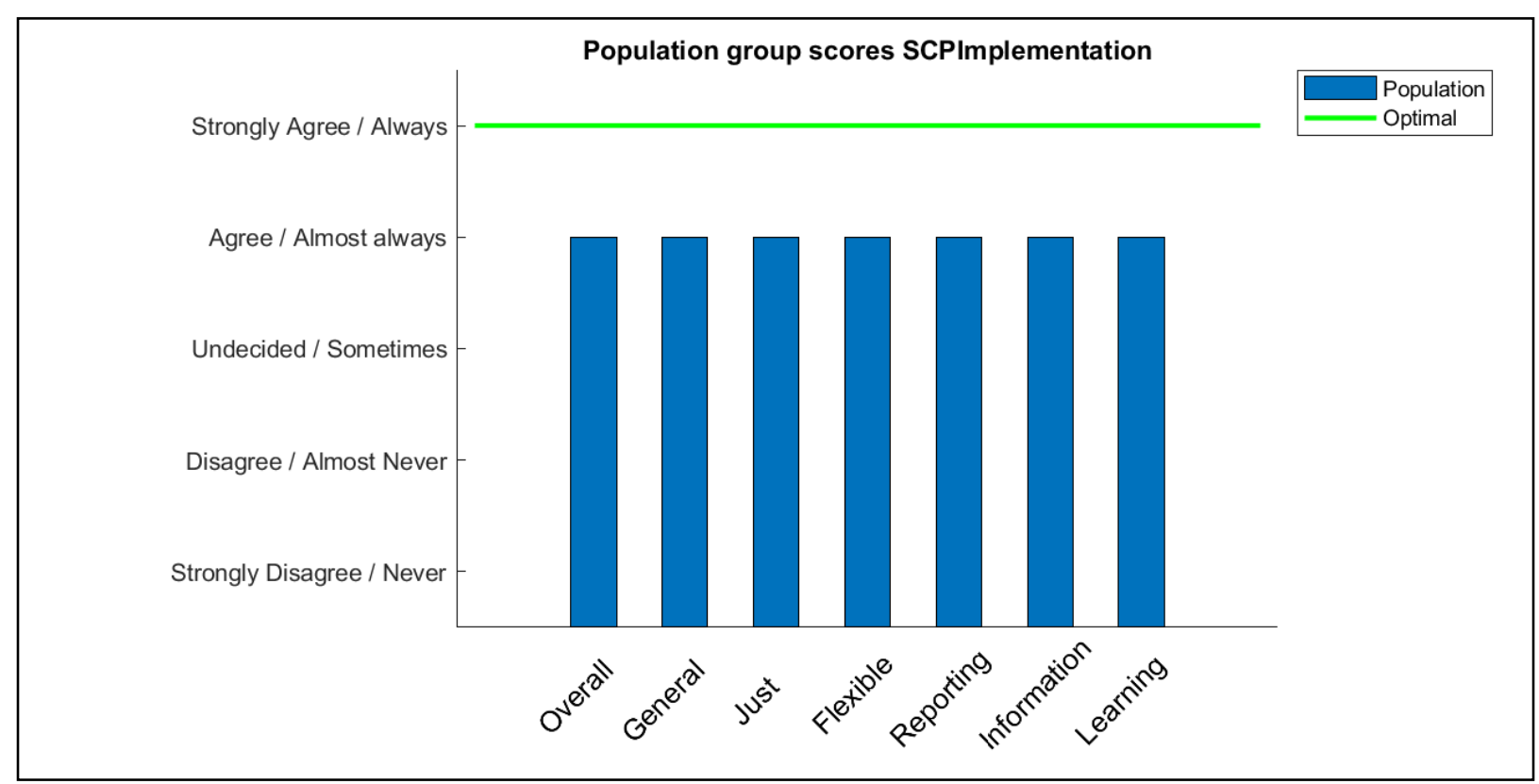

Figure 3: Population scores for the Implementation questionnaire

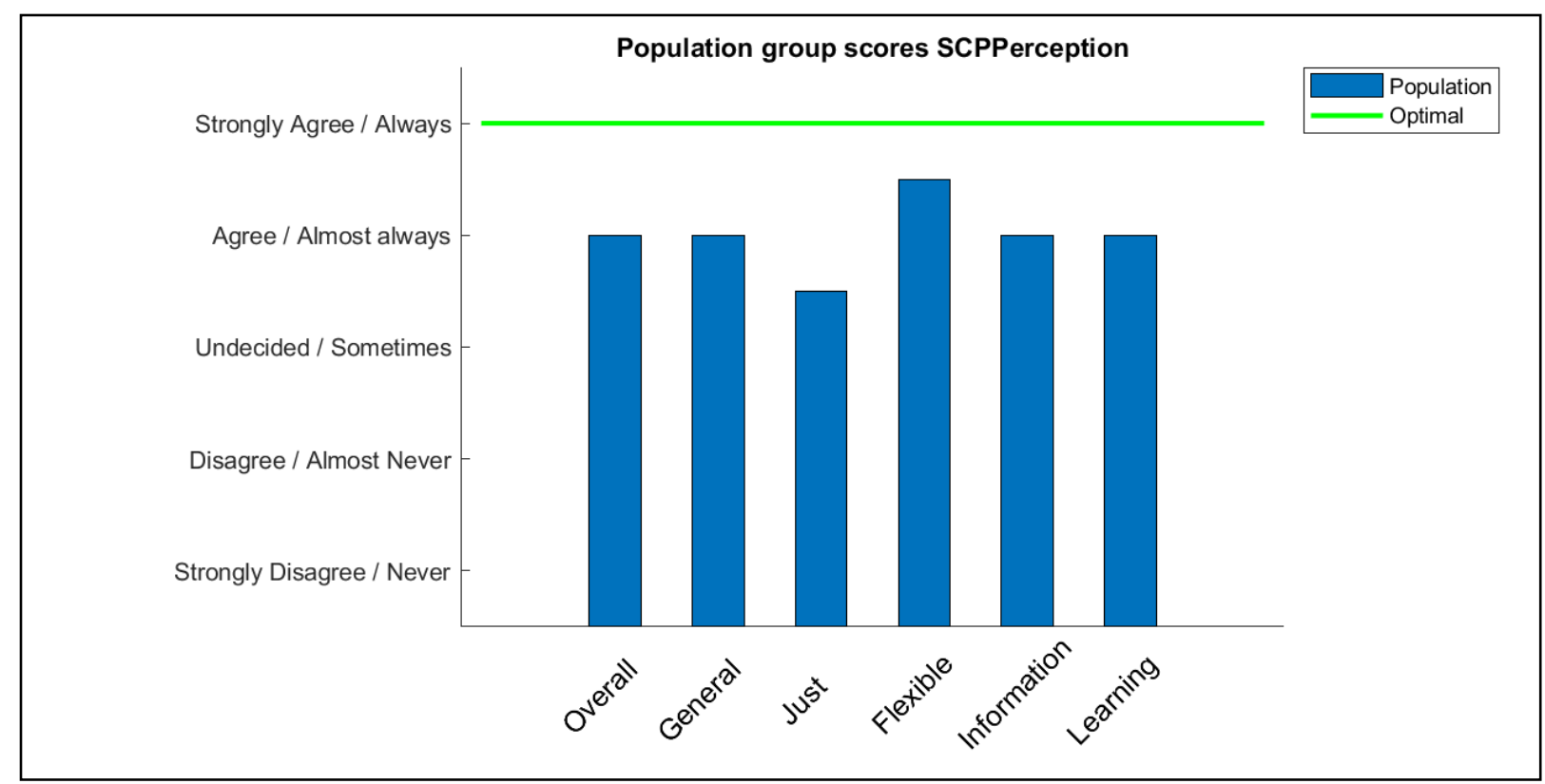

Figure 4: Population scores for the Perception questionnaire

The Spearman's correlation coefficients between the Implementation and Perception scores in overall and per subculture per company were not statistically significant. The correlations amongst subcultures within the Implementation and Perception aspects resulted in non-significant results for the latter, whereas regarding Implementation, the following significances were detected:

- General prerequisites were found associated with Just culture $(\mathrm{N}=14, \mathrm{r}=0.634, p=0.015)$ and Informative culture $(\mathrm{N}=14, \mathrm{r}=0.534, p=0.049)$.

- Just culture was additionally associated with Reporting culture $(N=14, r=0.599, p=0.024)$, Informative culture $(\mathrm{N}=14, \mathrm{r}=0.885, p=0.000)$ and Learning culture $(\mathrm{N}=14, \mathrm{r}=0.703, p=0.005)$. 
- Learning culture was also found correlated with Reporting culture $(\mathrm{N}=14, \mathrm{r}=0.637, p=0.014)$ and Informative culture $(\mathrm{N}=14, \mathrm{r}=0.736, p=0.003)$.

\section{DISCUSSION}

The overall results regarding Organizational plans showed that companies had adequately included most of the Safety Culture Prerequisites (SCP) in their documentation. However, the fact that Just culture plans scored the lowest and Reporting culture plans were found with the highest percentage indicates that companies might have not completely recognised that an environment of fairness is a precondition for an effective reporting system. The SCP referring to the Reporting culture regard the characteristics of the reporting policy and system; however, these might not deliver the expected outcome if the Just culture prerequisites lag significantly behind. Also, the scores per company showed that there might be big differences between specific organisations; nonetheless, the effects of national and local cultures should not also be neglected.

The level of SCP implementation was the same high as the organisational plans and quite uniform across the companies and sub-cultures. Thus, the discrepancy between Just and Reporting cultures detected in SCP plans was not found in the implementation. Comparing the subculture differences detected in the SCP plans, it seems that managers, on the one hand, were implementing more just culture elements and fewer reporting culture elements than prescribed in the company documentation; the former can be seen as a positive gap, but the latter as a negative one.

Furthermore, although the perceptions were at the same overall level with implementation, it seems that employees perceived the organisational environment as less fair and more flexible than managers claimed. This finding indicates a gap that can have detrimental effects over time; managers who perceive themselves as advocates of just culture might not realise that workforce does not observe this in practice, and employees might believe that they have more room for flexibility than managers have offered.

As far as the statistical associations concerned, the fact that the implementation of Just culture prerequisites was found significantly associated with all subcultures except Flexible subculture suggests the strong relationships between the fair working environment and the rest of the cultural aspects. Although the correlations detected do not infer causality, the particular finding seems supportive of the efforts placed recently to foster a just culture within organisations. Regarding the rest of the significant associations, the main message is rather that, in general, the different aspects of safety culture cannot be seen as completely independent from each other; this means, that a company focusing vastly on one subculture and underestimating the importance of other subcultures might not yield the maximum benefits.

\section{CONCLUSION}

The application of the AVAC-SCP metrics showed that it has adequate sensitivity to capture any gaps between Wal and $\mathrm{WaD}$ across organisations. Also, the application of the metric revealed interesting differences amongst subcultures as well as the Safety Culture Prerequisites assessment areas. However, the relatively small sample of companies and restricted number of managers and employees participating per company render the findings only indicative and not conclusive. Also, this limitation did not allow to perform comparisons between large companies and SMEs as well as amongst companies with different operational activities (i.e. airlines, air navigation service providers, airports and ground services). Although the study described in this report was exploratory and not explanatory, we believe that the results presented above in combination with the ones communicated to the companies can trigger the latter to investigate further their weaker areas and foster their activities related to SCP. Therefore, the AVAC-SCP metric is deemed useful to organisations that want to self-assess their SCP levels and proceed to comparisons amongst various functions and levels and/or over time.

Finally, although the research team required from companies to share their figures of the activity and safety data (e.g., number of safety incidents, volume of flights) as a means to check 
associations of these with the scores of the metric, the data collected was insufficient to perform statistical calculations. Therefore, at this stage, we could not determine whether the AVAC-SCP has any predictive validity. The researchers plan to run a second round of surveys to apply the metric and collect safety/activity data from more organizations. Hence we anticipate that we will be able to test the metric against safety performance and activity figures. Nonetheless, irrespective of the possible associations of the AVAC-SCP metric with safety outcomes, its application and findings communicated in this report are supportive of its usefulness, practicality and potential value for the companies that are interested in assessing their SCP, reveal gaps amongst the specific assessment areas of the metric and get insights into their strong and weak points to improve further the way they manage safety.

\section{ACKNOWLEDGEMENTS}

The researchers would like to express their deep thanks to the following organisations for participating in the AVAC-SCP survey: Aer Lingus (IE), Aeroporti di Roma (IT), Air Dolomiti (IT), ATNS (ZA), Av8jet (UK), Goldair Handling (GR), Kroger Co (US), TAG Aviation (UK), Napoli airportGESAC (IT), Oceania Aviation (NZ), Orio al Serio airport-SACBO (IT), Schiphol Airport (NL), Shell aircraft international (NL), Star Wings (DE), THAI Airlines (TA), and Volkswagen Airservice (DE).

\section{REFERENCES}

Aviation Academy. (2014). Project Plan RAAK PRO: Measuring safety in aviation - developing metrics for Safety Management Systems. The Netherlands: Amsterdam University of Applied Sciences, Aviation Academy.

Karanikas, N., Kaspers, S., Roelen, A., Piric, S., \& de Boer, R. (2016b). Review of Existing Aviation Safety Metrics, RAAK PRO Project: Measuring Safety in Aviation, Project S10931. The Netherlands: Amsterdam University of Applied Sciences, Aviation Academy. doi:10.13140/RG.2.2.35967.41128

Karanikas, N., Kaspers, S., Roelen, A., Piric, S., van Aalst, R., \& de Boer, R. (2016a). Results from Surveys about Existing Aviation Safety Metrics, RAAk PRO Project: Measuring Safety in Aviation, Project S10931. The Netherlands: Amsterdam University of Applied Sciences, Aviation Academy. doi:10.13140/RG.2.2.22545.63847

Karanikas, N., Kaspers, S., Roelen, A., Piric, S., van Aalst, R., \& de Boer, R. (2017). Five Novel Metrics to Support Safety Improvements in Current and Future Air Transport, 2. AERO journal, 21-27.

Karanikas, N., Soltani, P., de Boer, R., \& Roelen, A. (2016c). Safety Culture Development: the Gap Between Industry Guidelines and Literature, and the Differences Amongst Industry Sectors. In P. Arezes (Ed.), AHFE 2016 International Conference on Safety Management and Human Factors, July 27-31, 2016 (pp. 53-63). Florida, USA, Springer: Walt Disney World®. doi:10.1007/978-3-319-41929-9_7

Kaspers, S., Karanikas, N., Roelen, A., Piric, S., \& de Boer, R. (in press). How Does Aviation Industry Measure Safety Performance? Current Practice and Limitations. International Journal of Aviation Management.

Kaspers, S., Karanikas, N., Roelen, A., Piric, S., van Aalst, R., \& de Boer, R. (2016). Exploring the Diversity in Safety Measurement Practices: Empirical Results from Aviation. Proceedings of the 1st International Cross-Industry Safety Conference, Journal of Safety Studies, 2(2), (pp. 18-29). Amsterdam, 3 - 4 November 2016. doi:10.5296/jss.v2i2.10437

Kaspers, S., Karanikas, N., Roelen, A., Piric, S., van Aalst, R., \& de Boer, R. (2017). Measuring Safety in Aviation: Empirical Results about the Relation between Safety Outcomes and Safety Management System Processes, Operational Activities and Demographic Data. PESARO 2017: The Seventh International Conference on Performance, Safety and Robustness in Complex Systems and Applications, IARIA, (pp. 9-16).

NLR. (2016). ASC-IT: Seven steps to improve your safety culture. NLR-CR-2016-228. 
Piric, S., Karanikas, N., de Boer, R., Roelen, A., Kaspers, S., \& van Aalst, R. (2018). How much do Organizations Plan for a Positive Safety Culture? Introducing the Aviation Academy Safety Culture Prerequisites (AVAC-SCP) Tool. Proceedings of the International Cross-industry Safety Conference, 2-3 November 2017, 1(1), (pp. 118-129). Amsterdam University of Applied Sciences, AUP Advances. doi:10.5117/ADV2018.1.008.PIRI

Reason, J. (1998). Achieving a safe culture: theory and practice. Work \& Stress 12(3), 293-306. 


\section{APPENDIX A}

Table A.1: SCP Organizational Plans

\begin{tabular}{|c|c|c|c|c|}
\hline Code & Organisational Plans & Yes & Partially & No \\
\hline G.01-D & $\begin{array}{c}\text { There is a written commitment of management } \\
\text { towards safety. }\end{array}$ & $100,00 \%$ & $0,00 \%$ & $0,00 \%$ \\
\hline G.02-D & $\begin{array}{c}\text { Leadership is recognised as important for safety } \\
\text { culture development. }\end{array}$ & $96,67 \%$ & $0,00 \%$ & $3,33 \%$ \\
\hline G.03-D & $\begin{array}{l}\text { Responsibilities \& accountabilities for safety have } \\
\text { been defined across all management areas. }\end{array}$ & $88,00 \%$ & $12,00 \%$ & $0,00 \%$ \\
\hline G.04-D & $\begin{array}{l}\text { The safety department is responsible for safety } \\
\text { planning ("A basic element of the safety management } \\
\text { system (SMS) that enables the setting of } \\
\text { organisation's safety objective and targets, as well as } \\
\text { the identification of the necessary means and } \\
\text { resources for their achievement"). }\end{array}$ & $96,00 \%$ & $0,00 \%$ & $4,00 \%$ \\
\hline G.05-D & $\begin{array}{l}\text { The organisation requires employees' engagement } \\
\text { into: }\end{array}$ & & & \\
\hline G.05-D.1 & Initial planning activities & $69,33 \%$ & $0,00 \%$ & $30,67 \%$ \\
\hline G.05-D.2 & Monitoring activities & $98,67 \%$ & $0,00 \%$ & $1,33 \%$ \\
\hline G.05-D.3 & Improvement activities & $88,67 \%$ & $0,00 \%$ & $11,33 \%$ \\
\hline G.06-D & $\begin{array}{l}\text { The need for continuous improvement - regardless of } \\
\text { past successes - is acknowledged. }\end{array}$ & $100,00 \%$ & $0,00 \%$ & $0,00 \%$ \\
\hline G.07-D & $\begin{array}{l}\text { A risk management framework exists to be used in } \\
\text { decisions about changes and plans. }\end{array}$ & $90,00 \%$ & $0,00 \%$ & $10,00 \%$ \\
\hline G.08-D & $\begin{array}{l}\text { The risk management framework is tailored to each } \\
\text { organizational level, department or work instruction. }\end{array}$ & $39,89 \%$ & $37,44 \%$ & $22,67 \%$ \\
\hline G.09-D & $\begin{array}{l}\text { The organization acknowledges that buffers are } \\
\text { needed to cope with unexpected operational events. }\end{array}$ & $84,00 \%$ & $0,00 \%$ & $16,00 \%$ \\
\hline G.10-D & $\begin{array}{c}\text { There is a policy for rewarding exceptional } \\
\text { contributions to safety (such as new ideas, voluntary } \\
\text { participation in safety plans etc., but not daily } \\
\text { performance) }\end{array}$ & $30,89 \%$ & $0,00 \%$ & $69,11 \%$ \\
\hline G.11-D & $\begin{array}{l}\text { The organization has a platform to facilitate internal } \\
\text { communication. }\end{array}$ & $97,00 \%$ & $0,00 \%$ & $3,00 \%$ \\
\hline G.12-D & $\begin{array}{l}\text { The organization facilitates a questioning attitude } \\
\text { (e.g. peer reviews, brainstorm sessions, formalised } \\
\text { feedback) }\end{array}$ & $82,67 \%$ & $0,00 \%$ & $17,33 \%$ \\
\hline G.13-D & $\begin{array}{l}\text { The organization provides guidance in effective } \\
\text { conflict management. }\end{array}$ & $53,78 \%$ & $0,00 \%$ & $46,22 \%$ \\
\hline G.14-D & $\begin{array}{l}\text { The organization has communication channels with } \\
\text { society. }\end{array}$ & $90,33 \%$ & $0,00 \%$ & $9,67 \%$ \\
\hline G.15-D & $\begin{array}{c}\text { The organization has communication channels with } \\
\text { the authorities. }\end{array}$ & $100,00 \%$ & $0,00 \%$ & $0,00 \%$ \\
\hline G.16-D & $\begin{array}{c}\text { The organization has communication channels with } \\
\text { other sectors. }\end{array}$ & $90,00 \%$ & $0,00 \%$ & $10,00 \%$ \\
\hline J.1-D & $\begin{array}{c}\text { Documented definitions of "unacceptable" and/or } \\
\text { "acceptable" behaviours are defined, accompanied } \\
\text { by examples, assumptions, indications, and required } \\
\text { evidence etc. }\end{array}$ & $67,33 \%$ & $0,00 \%$ & $32,67 \%$ \\
\hline
\end{tabular}




\begin{tabular}{|c|c|c|c|c|}
\hline Code & \begin{tabular}{|l} 
Organisational Plans \\
\end{tabular} & Yes & Partially & No \\
\hline J.2-D & $\begin{array}{c}\text { The decision for evaluating unacceptable behaviour } \\
\text { is required to be made and agreed by a team } \\
\text { including peers. }\end{array}$ & $54,67 \%$ & $0,00 \%$ & $45,33 \%$ \\
\hline J.3-D & $\begin{array}{c}\text { Rights and duties of employees regarding safety } \\
\text { occurrences are described. }\end{array}$ & $93,33 \%$ & $0,00 \%$ & $6,67 \%$ \\
\hline J.4-D & $\begin{array}{c}\text { The description includes a list of indicative measures } \\
\text { and the cases that these might apply to. }\end{array}$ & $56,00 \%$ & $0,00 \%$ & $44,00 \%$ \\
\hline J.5-D & $\begin{array}{c}\text { Guidelines for prevention of stigmatization of } \\
\text { practitioners after an adverse outcome are provided. }\end{array}$ & $50,78 \%$ & $0,00 \%$ & $49,22 \%$ \\
\hline J.6-D & $\begin{array}{l}\text { In case of legal disputes the organization supports } \\
\text { individuals legally, financially, and/or psychologically. }\end{array}$ & $80,56 \%$ & $0,00 \%$ & $19,44 \%$ \\
\hline F.1-D & $\begin{array}{c}\text { The organization recognizes that there may be a } \\
\text { difference between rules and regulations and daily } \\
\text { activities. }\end{array}$ & $83,44 \%$ & $0,00 \%$ & $16,56 \%$ \\
\hline F.2-D & $\begin{array}{l}\text { Employees have the right to self-organize their tasks } \\
\text { within specific limits. }\end{array}$ & $60,67 \%$ & $0,00 \%$ & $39,33 \%$ \\
\hline F.3-D & $\begin{array}{l}\text { Emergency stop procedures are accessible to } \\
\text { employees when safety is compromised. }\end{array}$ & $84,67 \%$ & $0,00 \%$ & $15,33 \%$ \\
\hline F.4-D & $\begin{array}{c}\text { Scheduled emergency response exercises are } \\
\text { required. }\end{array}$ & $93,33 \%$ & $0,00 \%$ & $6,67 \%$ \\
\hline F.5-D & $\begin{array}{l}\begin{array}{l}\text { Unscheduled emergency response exercises are } \\
\text { foreseen. }\end{array} \\
\text {. }\end{array}$ & $77,00 \%$ & $0,00 \%$ & $23,00 \%$ \\
\hline R.1-D & There is a policy for safety reporting. & $96,67 \%$ & $0,00 \%$ & $3,33 \%$ \\
\hline R.2-D & The implications of safety reporting are described. & $96,67 \%$ & $0,00 \%$ & $3,33 \%$ \\
\hline R.3-D & $\begin{array}{l}\text { When it comes to reporting, definitions of who, what, } \\
\text { when, where, how/why are provided. }\end{array}$ & $79,33 \%$ & $19,33 \%$ & $1,33 \%$ \\
\hline R.4-D & Reporting is voluntary & $93,33 \%$ & $0,00 \%$ & $6,67 \%$ \\
\hline R.5-D & Reporting is non-punitive & $98,67 \%$ & $0,00 \%$ & $1,33 \%$ \\
\hline R.6-D & Rep & $92,86 \%$ & $0,00 \%$ & $7,14 \%$ \\
\hline R.7-D & Rep & $96,67 \%$ & $0,00 \%$ & $3,33 \%$ \\
\hline R.8-D & Reporting is e & $90,00 \%$ & $0,00 \%$ & $10,00 \%$ \\
\hline R.9-D & Reporter is provided with timely feedback & $82,67 \%$ & $0,00 \%$ & $17,33 \%$ \\
\hline I.1-D & A safety information system is in place. & $93,33 \%$ & $0,00 \%$ & $6,67 \%$ \\
\hline I.2-D & $\begin{array}{l}\text { The safety information system is required to be user- } \\
\text { friendly. }\end{array}$ & $92,00 \%$ & $0,00 \%$ & $8,00 \%$ \\
\hline I.3-D & $\begin{array}{l}\text { The safety information system is required to be freely } \\
\text { accessible to all employees. }\end{array}$ & $85,33 \%$ & $0,00 \%$ & $14,67 \%$ \\
\hline I.4-D & The safety information system & & & \\
\hline I.4-D.1 & $\begin{array}{r}\text { reactive safety informatio } \\
\text { investigation r€ }\end{array}$ & $93,33 \%$ & $0,00 \%$ & $6,67 \%$ \\
\hline I.4-D.2 & $\begin{array}{l}\text { proactive safety information (e. } \\
\text { voluntary reports, safety in }\end{array}$ & $83,33 \%$ & $0,00 \%$ & $16,67 \%$ \\
\hline I.4-D.3 & $\begin{array}{l}\text { internal safety topics (e.g., improvement plans, newly } \\
\text { introduced risk controls, safety management } \\
\text { documentation and changes) }\end{array}$ & $92,00 \%$ & $0,00 \%$ & $8,00 \%$ \\
\hline I.4-D.4 & $\begin{array}{c}\text { external safety topics (e.g., safety performance of the } \\
\text { sector/other organisations, safety initiatives from } \\
\text { authorities) }\end{array}$ & $80,67 \%$ & $0,00 \%$ & $19,33 \%$ \\
\hline I.5-D & $\begin{array}{c}\text { Time is allocated to employees' working schedules } \\
\text { for accessing safety information. }\end{array}$ & $46,89 \%$ & $0,00 \%$ & $53,11 \%$ \\
\hline
\end{tabular}




\begin{tabular}{|c|c|c|c|c|}
\hline Code & Organisational Plans & Yes & Partially & No \\
\hline I.6-D & $\begin{array}{l}\text { Sharing of safety information across the organization } \\
\text { through safety activities (safety meetings, workshops } \\
\text { etc.) is required. }\end{array}$ & $100,00 \%$ & $0,00 \%$ & $0,00 \%$ \\
\hline L.1-D & $\begin{array}{l}\text { The need to learn from safety failures (e.g. Safety } \\
\text { investigation reports, voluntary reports, audits) is } \\
\text { recognised. }\end{array}$ & $100,00 \%$ & $0,00 \%$ & $0,00 \%$ \\
\hline L.2-D & $\begin{array}{c}\text { During safety investigations, company policy urges } \\
\text { the organization to also examine successes relative } \\
\text { to the incident. }\end{array}$ & $47,67 \%$ & $0,00 \%$ & $52,33 \%$ \\
\hline L.3-D & $\begin{array}{l}\text { Documentation urges management and leaders to } \\
\text { promote safety successes across the organisation. }\end{array}$ & $77,67 \%$ & $0,00 \%$ & $22,33 \%$ \\
\hline L.4-D & $\begin{array}{c}\text { General training of all employees about safety } \\
\text { management is required. }\end{array}$ & $95,33 \%$ & $4,67 \%$ & $0,00 \%$ \\
\hline L.5-D & $\begin{array}{l}\text { Internal comparisons (e.g. across departments, units } \\
\text { or individual employees) are required. }\end{array}$ & $56,78 \%$ & $0,00 \%$ & $43,22 \%$ \\
\hline L.6-D & $\begin{array}{l}\text { External comparisons (e.g. with similar companies } \\
\text { and other sectors) are required. }\end{array}$ & $71,44 \%$ & $0,00 \%$ & $28,56 \%$ \\
\hline L.7-D & $\begin{array}{c}\text { Safety information is used to initiate policy and } \\
\text { attitude changes. }\end{array}$ & $95,71 \%$ & $0,00 \%$ & $4,29 \%$ \\
\hline
\end{tabular}


Table A.2: SCP Implementation

\begin{tabular}{|c|c|c|}
\hline \multicolumn{2}{|r|}{ Implementation } & Median \\
\hline G.01-I & My commitment towards safety is clearly visible. & 4,75 \\
\hline G.02-I & I take the lead in developing a positive safety culture. & 4,5 \\
\hline G.03-I & $\begin{array}{l}\text { Shifting between target-oriented (setting and achieving goals) and } \\
\text { transformational leadership styles (inspiring employees) is important for a } \\
\text { good safety culture. }\end{array}$ & 4,75 \\
\hline G.04-I & I am able to carry out my safety responsibilities. & 4 \\
\hline G.05-I & The safety department undertakes its responsibility for safety planning. & 4,25 \\
\hline G.06-I & I involve employees into: & \\
\hline G.06-I.1 & Initial planning activities? & 4 \\
\hline G.06-I.2 & Monitoring activities? & 4 \\
\hline G.06-I.3 & Improvement activities? & 4 \\
\hline G.07-I & I continuously aim to improve safety, regardless of past succ & 5 \\
\hline G.08-I & $\begin{array}{l}\text { How often do you base decisions, changes and plans on a risk management } \\
\text { framework? }\end{array}$ & 4 \\
\hline G.09-I & $\begin{array}{l}\text { Is the risk management framework applicable to the needs of your } \\
\text { department? }\end{array}$ & 4 \\
\hline G.10-I & I include operational buffers to cope with the unexpected. & 4 \\
\hline G.11-I & $\begin{array}{l}\text { I reward exceptional contributions to safety (such as new ideas, voluntary } \\
\text { participation in safety plans etc., but not daily performance)? }\end{array}$ & 4 \\
\hline G.12-I & I use available platforms to communicate about safety internally. & 4 \\
\hline G.13-I & $\begin{array}{l}\text { I facilitate a questioning attitude (e.g. peer reviews, brainstorm sessions, } \\
\text { formalised feedback). }\end{array}$ & 4 \\
\hline G.14-I & I am equipped to provide effective conflict management. & 4 \\
\hline G.15-I & I use available channels to communicate about safety extern & 4 \\
\hline G.16-I & I use available channels to communicate with the authorities. & 4 \\
\hline G.17-I & I use available channels to communicate with other sectors. & 4 \\
\hline J.1-I & $\begin{array}{c}\text { I use documented definitions of "unacceptable" and/or "acceptable" } \\
\text { behaviours to evaluate someone's behaviour. }\end{array}$ & 4 \\
\hline J.2-I & Unacceptable behaviour is evaluated by a team including peers. & 4 \\
\hline J.3-I & Rights and duties of employees regarding safety occurrences are known. & 4 \\
\hline J.4-I & I use this list of indicative measures and the cases when appropriate. & 4 \\
\hline J.5-I & $\begin{array}{l}\text { In cases of mistakes/errors (within the area of acceptable behaviour) that led } \\
\text { to adverse outcomes, support to employees to enable proper functioning in } \\
\text { their job is provided. }\end{array}$ & 4 \\
\hline J.6-I & $\begin{array}{l}\text { In cases of mistakes/errors (within the area of acceptable behaviour) that led } \\
\text { to adverse outcomes, legal/financial/psychological support to employees is } \\
\text { provided. }\end{array}$ & 4 \\
\hline F.1-I & $\begin{array}{l}\text { I recognize that there may be a difference between rules and regulations } \\
\text { and daily activities. }\end{array}$ & 3,25 \\
\hline F.2-I & To what extent employees have the right to self-organize their tasks? & 4 \\
\hline F.3-I & $\begin{array}{l}\text { Emergency stop procedures are used by employees when safety is } \\
\text { compromised. }\end{array}$ & 4 \\
\hline F.4-I & Scheduled emergency response exercises are executed. & 4 \\
\hline F.5-I & Unscheduled emergency response exercises are executed. & 3 \\
\hline R.1-I & $\begin{array}{l}\text { Safety occurrences, regardless of their severity, are reported by your } \\
\text { employees. }\end{array}$ & 4 \\
\hline R.2-I & The implications of reporting are known to the employees. & 4,25 \\
\hline R.3-I & All contextual information is provided in the report. & 4 \\
\hline R.4-I & Issues are reported voluntarily. & 4 \\
\hline
\end{tabular}




\begin{tabular}{|c|c|c|}
\hline \multicolumn{2}{|r|}{ Implementation } & Median \\
\hline R.5-I & Reporting is not punished. & 5 \\
\hline R.6-I & Contents of the reports remain confidential. & 4 \\
\hline R.7-I & Reporting is user-friendly in operation. & 4 \\
\hline R.8-I & Reporting is easily accessible in operation. & 4 \\
\hline R.9-I & Reporter is provided with timely feedback. & 4 \\
\hline I.1-I & $\begin{array}{c}\text { How frequently do you and your employees use the safety information } \\
\text { system? }\end{array}$ & 4 \\
\hline I.2-I & The safety information system is user-friendly. & 4 \\
\hline I.3-I & The safety information system is freely accessible to all employees. & 4 \\
\hline I.4-I & How frequently do you use the following types of safety information: & \\
\hline I.4-I.1 & reactive safety information (e.g., accident investigation reports) & 4 \\
\hline I.4-I.2 & $\begin{array}{c}\text { proactive safety information (e.g., trends derived from voluntary reports, } \\
\text { safety inspection/audits) }\end{array}$ & 4 \\
\hline I.4-I.3 & $\begin{array}{l}\text { internal safety topics (e.g., improvement plans, newly introduced risk } \\
\text { controls, safety management documentation and changes) }\end{array}$ & 4 \\
\hline I.4-I.4 & $\begin{array}{c}\text { external safety topics (e.g., safety performance of the sector/other } \\
\text { organisations, safety initiatives from authorities) }\end{array}$ & 4 \\
\hline I.5-I & $\begin{array}{l}\text { Time is allocated to employees' working schedules for accessing safety } \\
\text { information. }\end{array}$ & 4 \\
\hline I.6-I & $\begin{array}{c}\text { Safety information is shared across your employees through dedicated } \\
\text { safety activities (safety meetings, workshops, etc.) }\end{array}$ & 4 \\
\hline L.1-I & $\begin{array}{l}\text { Information from safety failures (e.g. safety investigation reports, safety } \\
\text { audits, voluntary reports) is used to improve learning. }\end{array}$ & 4 \\
\hline L.2-I & $\begin{array}{c}\text { During safety investigations, the organization also examines successes } \\
\text { relative to the incident. }\end{array}$ & 4 \\
\hline L.3-I & Safety successes are shared with the employees. & 4 \\
\hline L.4-I & General training of all employees about safety management is provided. & 4,25 \\
\hline L.5-I & $\begin{array}{c}\text { Lessons are learned from internal comparisons (e.g. across departments, } \\
\text { units or individual employees). }\end{array}$ & 4 \\
\hline L.6-I & $\begin{array}{c}\text { Lessons are learned from external comparisons (e.g. with similar companies } \\
\text { and other sectors). }\end{array}$ & 4 \\
\hline L.7-I & Safety information has been used to initiate policy and attitude changes. & 4 \\
\hline
\end{tabular}


Table A.3: SCP Perception

\begin{tabular}{|l|c|r|}
\hline \multicolumn{2}{|c|}{ Perception } & Median \\
\hline G.1-P & The management thinks 'finishing the work' is more important than safety. & 4,5 \\
\hline G.2-P & I do not follow regulations and procedures if they delay the operation. & 5 \\
\hline G.3-P & If I make safety a priority at work, I often don't have enough time to complete \\
my activities. & 4 \\
\hline G.4-P & Unnecessary risks are taken when carrying out the work. & 4 \\
\hline J.1-P & People who violate procedures or regulations are punished. & 3 \\
\hline J.2-P & My colleague is open about mistakes he/she makes. & 4 \\
\hline F.1-P & I am encouraged to draw attention to safety problems. & 4,5 \\
\hline I.1-P & Safety cannot be improved further in my field of work. & 4 \\
\hline I.2-P & Safety is always discussed during team meetings. & 4 \\
\hline L.1-P & After an incident, management takes action to prevent a repeat of the incident. & 4 \\
\hline
\end{tabular}

